Article

\title{
Remedial Measures for Erroneous Environmental Policies: Assessing Infrastructure Projects of Waste-to-Energy Incineration in Taiwan with a Case Study of the Taitung Incinerator
}

\author{
Lih-Ren Liu and Yuh-Ming Lee * \\ Institute of Natural Resources Management, National Taipei University, 151 University Road, \\ San Shia District, New Taipei City 23741, Taiwan; lihren@mail2000.com.tw \\ * Correspondence: yml@mail.ntpu.edu.tw; Tel.: +886-2-8674-1111 (ext. 67333) \\ Academic Editors: Harald Rohracher, Michael Ornetzeder and Philipp Späth \\ Received: 22 September 2016; Accepted: 30 November 2016; Published: 8 December 2016
}

\begin{abstract}
Taiwan, like many other countries, often incentivizes private investors to participate in the construction of infrastructures for environmental protection. The build-operate-transfer (BOT) or build-operate-own (BOO) model of financing public infrastructure was introduced to Taiwan in the 1990s. Among them, the construction of incinerators to treat the municipal solid waste using the BOT/BOO model was quite a success in the beginning. With the socio-technical change of lifestyle and waste generation, the amount of amount of trash dropped dramatically. The policy failed eventually, however, because the government over-estimated the trash quantity and refrained from inter-municipality cooperation to treat trash efficiently. This failure triggered a rash of intense debates and legal disputes. In the case of the Taitung incinerator, the 26th incinerator located in southeastern Taiwan, the arbitration resulted in the government making significant compensation payments to the private sector. The finished construction was consequently converted into a "mothballed and pensioned off" facility. This study applies in-depth interviews and literature review to discuss aspects contributing to the policy failure and proposes some possible remedial measures. Five aspects are summarized, namely, the administrative organization's rigid attitude, the irrationality of the BOT / BOO contracts, the loss of the spirit of BOO partnerships, the heavy financial burden on local government, and the abandonment of inter-municipality cooperation. The remedial measures for the policy failure are presented in the form of thorough policy evaluation, room for contract adjustments under the BOT/BOO model, encouragement of cross-boundary cooperation, and revision of the legal framework for implementing decentralization.
\end{abstract}

Keywords: environmental governance; waste-to-energy incinerator; public-private partnership; inter-municipality cooperation

\section{Introduction}

One of the characteristics of traditional public administration is the expansion of government bureaucracy. Although the expansion is administered according to the law, private participation in public service is conspicuously hindered. It also results in a major drawback of government work-ubiquitous inefficiency. Since the 1980s, an academic wave called the New Public Management has been sweeping across the globe. It argues that governments should learn from management practices executed by private enterprises, encouraging public-private personnel exchanges, and emphasizing performance-oriented management. It contains the idea that citizens should position themselves as not only recipients of government services, but also participants in government processes [1]. Inspired by the New Public Management, governments have pushed for administrative 
reform to streamline organizational structures. They have also introduced marketization and liberalization measures. Public-private partnerships have, thus, emerged in all civic service-related projects of the government. These relationships usually ease the government's financial burden. Civil engagement in the construction of public works has become an important strategic policy. Wherever there is room for private sectors to participate in the planning of new public works, their participation and, therefore, their partnership, is welcomed. In general, the build-operate-transfer (BOT) model provides the main avenue for private industry to participate in governmental construction projects. At the end of the concession agreement term, all rights to the project are transferred to the government. In the build-own-operate (BOO) model, private sectors build and operate construction projects in accordance with government policy, but retain all of the rights to the finished projects.

As observed in Hsu [2], both the BOT and the BOO models are characterized by (1) government concessions: private industry can carry out financing and construction and within a specified operating window, can collect fees from users and generate profits with the government's endorsement; as well as (2) private participation: private industry, due to its flexibility and creativeness, can be offered further business opportunities as incentives to participate in public construction. Private participation in public construction involves special administrative concessions related to civil rights, administrative oversight, and legal responsibilities. Therefore, interactions between private industry participants and the public need to be conducted "in the public interests" [2]. Our study intends to stress the common features between the BOT and BOO models. In the case study to be presented later, both BOT and BOO models are adopted by the government with the single and foremost goal of attracting private investors to participate in public construction projects. Due to the high degree of similarities between the BOT and $\mathrm{BOO}$ models in terms of approaches and goals our study has, thus, integrated them into the "BOT/BOO model" (in the singular form instead of the plural form).

Savas [3] (pp. 244-247) pointed out that government endorsements of the BOT/BOO model in the form of guaranteed minimum quantity of operations are a powerful incentive for private industry to invest. Therefore, the BOT/BOO model is generally applied in most countries in the world, such as the United States (toll highways in California and Virginia, the New York JFK Airport terminal) and China (highways from Hangzou to Hong Kong and Macao). Experiences from these countries show that the BOT/BOO model can indeed help the government in solving most of the complicated problems. Ashuri et al. [4] collected examples of the application of the BOT/BOO model to entice private investors to renovate some outdated U.S. highways as government funding was limited. However, the BOT/BOO model has not always proved effective. Khan et al. [5] described an example from Pakistan where a BOT project failed due to an unstable government and high risk on lending banks. Zhao et al. [6,7] also argued that uncertainties in governmental stability, technical skills of engineering contractors, and management skills of participating private industries are the risks faced by BOT/BOO investors in China.

As for Taiwan, the Act for Promotion of Private Participation in Infrastructure Projects promulgated in February 2000. Part three of the Act [8] elaborates the following list of public constructions: transportation and tunnel infrastructures, pollution prevention and treatment facilities, sewage lines, water supply systems, sanitation and healthcare facilities, social and labor welfare facilities, cultural and educational facilities, major tourism and recreational facilities, electricity and energy service facilities, development of new towns, etc. In a study by Wang and Zeng [9] using the Delphi technique, BOT/BOO projects of hospitals, parking lots, recreational areas, worker housing, and incinerators are considered more attractive to private industry to participate and, thus, more effective in Taiwan. However, there are still conflicts between government and private industry affecting the construction progress. These conflicts mainly arise due to stakeholders' varying demands, long construction periods, unclear delineation of the government's responsibilities, banks exposed to increasing risks due to financial leverage, and changing regulations, etc. [10]. In addition, the length of concession periods and fluctuating exchange rates are the biggest risk factors in BOT/BOO projects [11-13]. As soon as disputes arise in BOT/BOO projects, Su [10] further argued that such cases 
belong in the domain of private contracts, but the government should intervene administratively and arbitrations need to be conducted.

Taiwan, like many other countries, often incentivizes private investors to participate in the construction and operation of large public facilities for environmental protection. It is simply too difficult for the government to raise sufficient funds to complete all such projects alone. In the 1990s, Taiwan started promoting the construction of incinerator plants using BOT/BOO method and a "one incinerator per county" policy. The policy failed, however, because the government incorrectly estimated the quantity of trash that would need to be incinerated. This failure triggered a rash of heated debates and legal disputes. In the case of the Taitung incinerator plant, arbitration resulted in the government making significant compensation payments to the private sector. In order to satisfy legal requirements, a "finish work but do not use" policy was developed and the plant was mothballed.

This study examines the factors that the government took into consideration when seeking redress for its failed environmental policy. It searches for lessons learned from this experience that can be applied to future projects that aim to adopt BOT/BOO cooperation model. To accomplish such a goal, the study collects existing literature from a range as broad as possible and combines literature review and a case study with in-depth interviews. It has endeavored to not only approach the controversies surrounding the BOT/BOO model of financing public infrastructure from the perspective of social policies, but also offer remedial measures for the policy failure.

\section{Policy Failure: Taiwan Incineration Plants Construction Policy}

The Waste Disposal Act (WDA) [14], promulgated in Taiwan by presidential order in 1974, is the special law for waste management. The Act sets out a framework for waste management, covering areas such as waste classifications; responsibilities of governments, enterprises and citizens; as well as standards and rules for waste storage, recycling, clearance and disposal. It stipulated that solid waste shall be divided into two categories according to its generators: general waste and industrial waste. The former is defined as "waste from households or other non-industrial sources" and can be commonly referred to as the municipal solid waste (MSW) or simply trash. Local municipalities (city or county governments) being responsible for clearance (collection), treatment, and disposal of general waste is also prescribed by the Act. As for recycling, the Taiwan Environmental Protection Administration (TEPA), designated by the Act as the central competent authority, has defined post-consumer products as "regulated recyclable wastes", which is to be handled by manufacturers, importers, and sellers of such products or packaging.

According to the statistics and descriptions released at the webpages of TEPA (http:/ / www.epa. gov.tw), the treatment and disposal of MSW in Taiwan can be summarized as the following: in the past, Taiwan used landfills for the MSW. However, as the quantity of trash continued to increase, between 1980 and 1990, it became clear that burying trash was no longer effective. The Executive Yuan in Taiwan approved in 1991 the Waste Recycling Plants (Incinerators) Construction Project proposed by the TEPA. In the end, there were 21 incinerators constructed by the public sectors in the late 1990s. Five of these were "publically owned and publically operated", and the other 16 were "publically owned and privately operated". During 1997-1998, 15 more incinerators, mainly using the BOT/BOO model, were approved to be constructed based on a one-incinerator-in-one-county policy and an ambitious waste generation annual growth rate of just 5\%. In 1997, the TEPA launched the Four-in-One Recycling Program to enlist community residents, recyclers, local governments, and the Recycling Management Fund for the task of recycling. The program, designed to encourage the public to participate, relies on households or communities to sort household trash, which are then separately collected by local governments or private collection teams. The Recycling Management Fund is in overall charge of managing and subsidizing the processing and recovery of recyclables.

In actuality, however, starting in 1993, the annual growth rate of waste generation never exceeded $4 \%$. In addition, the successes of the Four-in-One Recycling Program actually led to negative growth in trash production and a dramatic increase in the recycling rate (Figure 1). The incinerator 
capacity that the TEPA had approved by 1998 was 30,400 metric tons per day (tonnes/day). This amount far exceeded the trash amount at the time (24,330 tonnes/day, equivalent to $1.135 \mathrm{~kg}$ per capita per day). However, the TEPA failed to promptly review and correct the plan. The excessive incinerator capacity margin was not discovered until April 2001. By that time, the amount of trash had already dropped to 19,937 tonnes/day, equivalent to $0.889 \mathrm{~kg}$ per capita per day. Therefore, between 2003 and 2006, construction of 10 incinerator facilities was halted. As a result, the total number of approved facilities dropped from 36 to 26 . The treatment capacity of the revised design was 25,550 tonnes/day. At the current moment, trash amount continues to fall to 8866 tonnes/day, equivalent to $0.378 \mathrm{~kg}$ per capita per day.

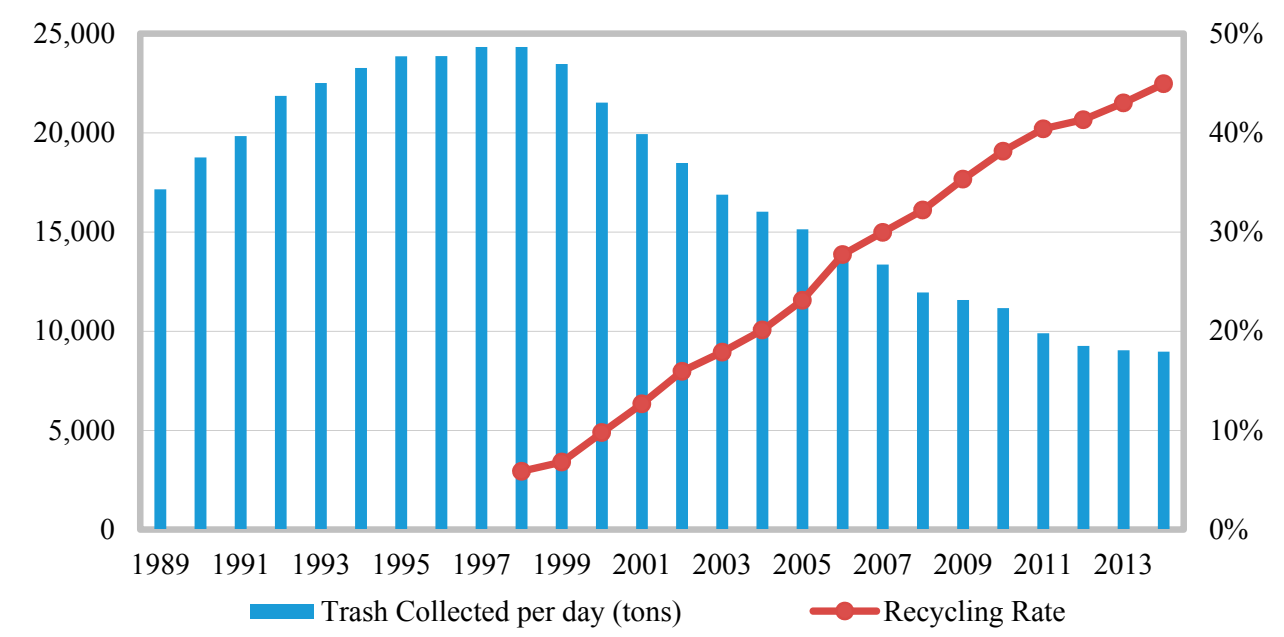

Figure 1. Trash collected per day (1989-2014) and recycling rate (1998-2014). Data source: Yearbook of Environmental Protection Statistics, Republic of China, 2006 through 2015 (http: / www.epa.gov.tw / np.asp?ctNode $=31088 \& \mathrm{mp}=\mathrm{epa})$.

After several years of construction work, 24 of the 26 incinerators have already entered the operation phase in the early 2008. Operations at the Taitung County and Yunlin County incinerators have not begun due to contract disputes. The 10 incinerator projects that were scrapped have resulted in six disputes over losses incurred by the contracted private companies. These disputes have subsequently turned to arbitration and civil litigation. In regard to the TEPA's mistakes in the incinerator policy, the Control Yuan redressed the TEPA in 2010 in terms of its failure to provide timely revised estimates for incinerator construction planning and negligence in its inefficient, five-year-long revision of incinerator construction plans. These mistakes resulted in the squandering of over 120 million New Taiwan Dollars (NTD, 1 NTD $\approx 0.03$ USD) worth of administrative expenses before work stoppage on the scrapped incinerator construction projects. Currently, for the two incinerators built yet with contract disputes, only the case of Taitung incinerator has been resolved. The crisis of Yunlin incinerator remains unsettled.

\section{A Case Study Based on Policy Analysis}

\subsection{Analysis Method and Case Description}

This study applies the methods of in-depth interview and literature review to the analysis of erroneous environmental policy of incinerator constructions. Targeted interviewees were government officials and the staff of the contracted company involved at the time. The Director of Incinerator Construction Department, TEPA, Mr. Chen, was interviewed on 13 May 2013. The Minister of TEPA, Dr. Shen, was interviewed on 19 March 2014. The General Manager of the commissioned company, Mr. Chen, was interviewed on 18 March 2014. This study prepared unstructured questions in advance and recorded completely the conversation during the interviews. Focuses, issues, and arguments were, 
thereafter, summarized according the compilation of the records. The questions asked and discussed include: (1) How did the disputes develop? (2) Why did the amount of trash over-estimate? (3) Were there any potentials for further BOT/BOO environmental infrastructures? (4) Would private enterprise participate public construction projects in the future, etc.?

The case to be investigated is the Taitung incinerator, one of the two incinerators that have been built but have not entered the operation phase. Taitung County is located in Southeastern Taiwan, with a population of about 234,000 , it occupies an area of $3515 \mathrm{~km}^{2}$, covering $9.78 \%$ of the total land of Taiwan. The Taitung incinerator was promoted with the BOO model. In other words, the commissioned company (the winning bidder) was responsible for acquiring the land, raising money for construction, and building the plant. After 20 years of operation, ownership would revert to the company. Construction funds would be reimbursed by the Taitung County government with depreciation rates determined by the TEPA.

This program was signed in 2001 and work began in 2002. The treatment capacity was set at 300 tonnes/day. As described earlier, after the contracts were signed, waste generation in Taitung County decreased dramatically. By the time the construction was completed, that is, in 2009, the trash amount collected in the Taitung County dropped to 114 tonnes/day. The incinerator, already built, was faced with problems including a shortage of trash and operating costs beyond original estimates. The Taitung government decided to suspend operation of the incinerator. In response to the decision, the construction company proposed contract termination arbitration and requested the Taitung County to buy back the plant for 2960 million NTD to compensate for damages. On 31 March 2011, the result of the arbitration required that the Taitung County had to buy back the plant for 1966 million NTD [15].

The arbitration result entitled the contracted company to take forceful legal actions. If the Taitung County had refused to abide by the results of the arbitration, there would have been a forced closure of the county's treasury and auctioning off of the county possessions. Although the central government of Taiwan promised to subsidize the construction with 2173 million NTD in the beginning, the TEPA would not help bail out the Taitung County unless the incinerator is in full operation. After a thorough financial analysis and lengthy negotiations, the Taitung County accepted the TEPA's proposition to designate the facility as a "functional backup plant". The Taitung County government was bailed out from the dispute for the moment. What follows below describes the assessment and resolution of this case.

\subsection{Policy-Making and Scenario Analysis}

In general, when policy-makers set policy, they first establish a set of criteria for policy selection. Through these criteria, clear relationships are established between policy objectives, program selection, and program effects. The most common policy-making methods are cost-benefit analysis or cost-effectiveness analysis. In the case of Taitung incinerator, reducing the government's financial burden became the sole criterion driving decisions. The central government officials of the TEPA understood very clearly that, due to their over-estimate of waste generation, the private participants in the government's construction project suffered losses. If the crisis had not been settled quickly, government officials would have been held responsible. Furthermore, the sooner the issue was resolved, the less the government's financial burden would be.

Rational policy-makers usually pursue the most effective approach when making decisions. This study interviewed two TEPA officials in charge of policy making and supervision of the incinerator construction. They stated that the highest priority in handling the Taitung incinerator case was to minimize the government's financial burden. Therefore, after the result of the arbitration came out, the government formulated three different options for paying back the ordered compensation to the construction company. Subtracting four years of dispute resolution, the commission period or the life-time of the incinerator is 16 years remained. The three options were set and assessed based on a depreciation period of 16 years: (1) refurbishing the incinerator for normal operation for 16 years; (2) maintaining functionalities of the incinerator (operated once a year) and converting it to 
an emergency and disaster response facility; and (3) mothballing the facility and keeping it in ready reserve [16].

Financial burden of the three options were calculated and listed in Table 1. Possible costs are categorized into: (1) compensation in installments for the construction company; (2) refurbishing/mothballing costs; and (3) operation expenses and/or treatment costs of transporting trash to other incinerators. In the end, calculations of financial burdens of the three options can be summarized as the followings.

[Table 1: Detailed items calculating costs of the three options (in thousand NTD)]

Option (I) Refurbishing for normal operation: Reimbursing the construction company according to the arbitration result, and then operating of the incinerator for 16 years, would cost 4100 million NTD, including operating costs, staff payroll, maintenance costs, etc.

Option (II) Maintaining functionalities: After reimbursing the construction company according to the arbitration result, the incinerator would be converted to an emergency and disaster response facility. To maintain and check its functionalities, the incinerator would be operated once a year. Taitung's trash would be transported to other incinerators. After 16 years, the total cost to the government, including operating costs, human resources, maintenance fees, etc. would be 3794 million NTD.

Option(III) Mothballing: After the government repays the construction company according to the results of the arbitration, the incinerator is mothballed and regarded as a backup facility. Trash would be transferred to other incinerators. After 16 years, the total cost, including operational costs, human resources, maintenance, etc. would be 3073 million NTD.

Presented with the three options to remediate its erroneous policy, the TEPA focused on how to decrease its financial burden within the limits of law. When TEPA policy-makers were interviewed for this study, they indicated that, due to legal requirements, the plant should be verified to be fully functional before the TEPA could issue a grant to the Taitung County. After analyzing the financial burden, Option (III) was selected because it poses the minimum remedial costs. The TEPA, therefore, strongly advised the Magistrate of the Taitung County to choose that option. 
Table 1. Detailed items calculating the costs of three options (in thousand NTD).

\begin{tabular}{|c|c|c|c|c|c|}
\hline \multicolumn{2}{|c|}{ I. Refurbishing for Normal Function } & \multicolumn{2}{|c|}{ II. Maintaining Functionalities } & \multicolumn{2}{|l|}{ III. Mothballing } \\
\hline 0. Installment to repay TEPA's aids & $2,223,270$ & 0. Installment to repay TEPA's aids & $2,223,270$ & 0. Installment to repay TEPA's aids & $2,223,270$ \\
\hline 1. Refurbishing costs & 127,030 & 1. Refurbishing costs & 127,030 & 1. Mothballing costs & 105,020 \\
\hline 1.1. Equipment inspections/updates & 40,640 & 1.1 Equipment inspections/updates & 40,640 & 1.1. Demolition of deficient units & 5000 \\
\hline 1.2. System testing/commissioning & 73,920 & 1.2 System testing/commissioning & 73,920 & 1.2. Related licenses and permits & 1300 \\
\hline 1.3. Other costs or expenses & 12,470 & 1.3 Other costs or expenses & 12,470 & 1.3. Security/maintenance/insurance & 98,720 \\
\hline 2. Operating expenses & $1,754,100$ & 2. Maintenance expenses & 847,500 & & \\
\hline 2.1. Operational overhead & $1,354,500$ & 2.1 Regular maintenance costs & 464,100 & & \\
\hline 2.2. On-site worker salaries & 26,100 & 2.2 Emergent operation costs & 383,400 & & \\
\hline 2.3. Trash transport & 67,500 & & & & \\
\hline 2.4. Ash and slag disposal & 27,150 & & & & \\
\hline 2.5. Monitoring expenses & 8400 & & & & \\
\hline \multirow[t]{2}{*}{ 2.6. Feedback compensations } & 270,450 & & & & \\
\hline & & $\begin{array}{l}\text { 3. Treatment costs of transporting } \\
\text { trash to other incinerators }\end{array}$ & 596,550 & $\begin{array}{l}\text { 3. Treatment costs of transporting } \\
\text { trash to other incinerators }\end{array}$ & 745,050 \\
\hline Total costs & $4,104,400$ & Total costs & $3,794,350$ & Total costs & $3,073,340$ \\
\hline
\end{tabular}

Data source: TEPA [16]. 


\subsection{Decision Process and Policy Analysis}

In Taiwan, elected county magistrates or city mayors have significant influence in their respective jurisdictions. They, however, still have to demonstrate their ability to handle crises to win over enough voters to keep them in office. The TEPA informed the Taitung government about the decision on the Taitung incinerator crisis: if the Taitung County was willing to accept the arbitration results and maintain full operability of the incinerator, the TEPA would grant financial bailout assistance. Naturally, the Magistrate of Taitung County, Jianting Huang, accepted the TEPA's proposal. He also wrote to the media saying that, although converting the Taitung County's incinerator into a back-up facility would be expensive due to payments to the construction company, the TEPA would continue to provide financial support for the next sixteen years. These compensation payments would be gradually returned to the Taitung County. The result would be that the TEPA would have helped the Taitung County acquire an incinerator that could be used in the future if needed. There would not be any need to ask for help from other counties to dispose trash. It was indeed a win-win situation. Huang treated the fiasco as a political achievement, which helped him win his re-election in 2014.

Based on the interviews of the TEPA officials [17], it can be concluded that the Taitung incinerator crisis is clearly an example of the great power wielded by the county chief executive. Moreover, the Taitung County Council trusted the Magistrate Huang and agreed with his methods to solve the problem through reasonable alternatives. The resolution of such affair involves conversations among local and central governmental officials, negotiations between public and private sectors, as well as political dialogues amongst elected chief executives and county council members. This study thus reviews related literature to further discuss private-public-partnership, political stewardship, and decision-making criteria in policy-making.

Chen and Subprasom [18] argue that public policy decisions may not be matters of overall cost effectiveness for society, but cost-benefit analysis problems for political parties, politicians, organizations, and other powerful stakeholders. Chiou [19] points out the importance of votes, that is, votes mean everything to local politicians. In need of votes, politicians could remain ignorantly aligned with public opinions even when faced with opposing academic or professional suggestions. In general, policy-makers all have their own political considerations, but the most important one is the incorporation of public opinions. If public opinions are ignored, policies will be boycotted, and the policy-maker's very job may be at risk. Gerston [20] (p. 167) says that one of the principles of policy development is that policy-makers may utilize their resources and abilities through a combination of public policies and political principles to reduce conflicts and solve problems. This research clearly reveals some obvious political considerations.

In addition, to promote a policy, it is necessary to analyze its feasibility, including economical, administrative, societal, and political feasibility [19]. Analyzing the Taitung incinerator policy from these four viewpoints, the most economical choice is the one that costs the least. Administratively, once the county government can verify the operability of the incinerator, the TEPA will grant legal assistance. Since the incinerator has not entered the operation phase, protest against the incinerator may not occur and hence societal supports, to some extent, can be attained. Politically, dialogues amongst the magistrate and county council members can lubricate the administrative progress of county affairs and further help politicians get votes. Yet, the TEPA seemed not to think about the future expenditures of re-activating the mothballed incinerator. This study, thus, would like to argue that the above-mentioned Option (III) resolved the crisis politically through mothballing but in reality, this incinerator can be considered "mothballed and ultimately pensioned off" due to economic and technical obstacles of re-activating the incinerator.

\section{Discussion and Arguments}

From arguments raised by $\mathrm{Yu}$ and $\mathrm{Qu}$ and Tam [21,22], it can be summarized that for a BOT/BOO project to succeed, there needs to be high financial feasibility in terms of fund-raising. There must also be high administrative efficiency and a harmonious political atmosphere. The democratic process 
must be fair and transparent. Investors must have sufficient experiences in financial leverage and construction technology. Lastly, public and private sectors must build successful partnerships. Based on research of the case of the Taitung incinerator dispute, five aspects contributing to the policy failure can be found. They are: the administrative organization's rigid attitude, the irrationality of the BOT / BOO contracts, the loss of the spirit of BOO partnerships, the heavy financial burden on local government, and the abandonment of inter-municipality cooperation. With the policy failure causes identified, this study continues with proposals of possible remedial measures based on the findings from literature review and the in-depth interviews.

\subsection{Policy Failure of the Taitung Incinerator Project}

\subsubsection{Rigid Administrate Responses and Lack of Criticism over Policy Errors}

Public policy is formed from a conglomeration of research, need, problems, and other factors. However, merely setting policy does not guarantee that policy objectives will be achieved. A professional bureaucracy will revise policy in a timely manner. In this case of the Taitung incinerator dispute, contracts were signed in 2001. Work began in 2002 with a designed treatment capacity of 300 tonnes/day. In 2009, the quantity of the total amount of trash to be incinerated was only 114 tonnes/day. The Taitung government judged that, according to the contract, operation would not cover operating costs. In February 2002, a letter was sent to the TEPA asking whether or not to halt construction of the Taitung incinerator [15]. However, the TEPA did not accept it. Had construction stopped at this point, the huge compensation payments that had to be made later could have been avoided. The government's rigidity and lack of administrative ability caused huge losses from the government treasury.

\subsubsection{Irrational Contracts and Inflexibility of Adjustments}

In order to make BOO or BOT projects succeed, governments often guarantee a minimum level of operational revenue, or subsidies [23]. Such guarantees and assurances increase the incentive for private sectors to participate. In this case, in order to encourage private enterprises to participate in the BOO plan, the contract clearly guaranteed a quantity of municipal solid waste to be treated. After the estimated trash quantity failed to materialize, contract limitations prevented changes to the guaranteed quantity of waste. It is apparent that there was no room for maneuver under the erroneous policy. When contracts were inked, there should have been built-in mechanisms to make adjustments. When the policy environment changed, the contractual specifications should have changed accordingly. Each side could have taken a step back, reduced the quantity of expected operations and, thus, also reduced the probability that the $\mathrm{BOO}$ program would fail.

\subsubsection{Untrustworthy Government and the Loss of the BOO Spirit of Partnership}

From the perspective of private industry participating in the Taitung incinerator project, it was not anticipated that the public-private partnership would suddenly change to a public-private dispute. Based on the interviews of representatives of private enterprises conducted for this study [24], they said that it never crossed their mind that the government's policy could fail. The incident has already affected private industry's willingness to invest in other public work projects for environmental protection. One characteristic of the BOO or BOT model is government concessions and endorsements. The government should use its administrative power to strengthen public-private cooperation and reduce the risk associated with $\mathrm{BOO}$ projects $[25,26]$. However, in this case, the government actually increased $\mathrm{BOO}$ risks and brought harms to the $\mathrm{BOO}$ as an institution.

\subsubsection{Heavy Financial Burden Decreases Supports from the Local Government}

Of the 24 operational incinerators in Taiwan today, 16 are publicly owned and privately operated; five are publicly owned and operated; and three use BOT or BOO. The majority are publicly owned 
and privately operated. When the local officials responsible for the actual bidding, construction, and operation of the Taitung incinerator were interviewed for this study, they expressed the opinion that the TEPA's method of guaranteeing the quantity of trash, when it was promoting the incinerator project, could attract private capital. The costs to treat the trash were to be paid by the local government, which put financial stress on the local government. If construction was handled by a government entity, operational problems could be minimized. This would prove true whether the plant was operated by the government or by private industry.

\subsubsection{Insistency of Decentralization and Abstaining from Inter-County Cooperation}

As regulated by Article 5 of the WDA [14], the recycling, clearance and disposal of general waste (collection and treatment of trash) shall be accomplished by local municipalities (city or county governments). This regulation led to the inappropriate one-incinerator-in-one-county policy and refrained from cooperation among local governments. As a matter of fact, Taiwan is relatively a medium-size island. The transportation distance of trash among counties would hardly exceed $300 \mathrm{~km}$. Inter-county cooperation could be an efficient way to treat trash. However, due to the above regulation and political insistency of decentralization, both the center and local governments relinquish such valuable opportunity and, thereafter, the merits of cross-boundary or inter-municipality cooperation.

\subsection{Arguments about Remedial Measures of the Policy Failure}

\subsubsection{Thorough Policy Evaluation and Contract Adjustments of the BOT/BOO Model}

No matter how well they are planned, large-scale development programs all have associated risks. The BOT/BOO projects are no exception. In the case of the Taitung incinerator, there was an erroneous estimate of the trash quantity. The market-based revenue model used in this BOO project included demand risk that affected both financial planning and operations. However, the BOT/BOO model has the advantage of reducing the financial burden on governments. Governments can simultaneously promote several urgently needed construction projects, even with limited time and financial resources. Additionally, private management techniques can improve the efficiency of public construction planning [18]. Thus, the BOT/BOO model of constructing public facilities have been widely applied throughout the world, as do several large-scale construction projects in Taiwan. Future public constructions related to environmental protection could also use the BOT/BOO model, but the government should learn from the mistakes of the Taitung incinerator and do a better job of evaluating its policy to avoid similar failures.

Governments can use two types of policy instruments to increase the operational efficiency of the winning bidders. One of them is to extend the concession period. The other is the implementation of price controls $[18,27,28]$. In this case, when the contracts were signed, the government could have offered an option to apply for an extension of the concession period as a reward for quality operations during the initial concession period. In terms of price controls, since private industry obtained special government permission to operate as a monopoly, the government could have used price controls as an operational incentive. As for how to set an appropriate time limit on concessions, other than cost-benefit calculations, the government must also have good negotiation skills to achieve its objectives [29].

\subsubsection{Encouraging Cross-Boundary Cooperation and the Revision of Legitimate Framework}

As discussed previously, the transportation of trash within the island is not a technical issue. The treatment of the MSW should be carried out in a more efficient and flexible way. Tang and Chen [30] mention that in the provision of public goods there are ideal economies of scale. Policy-makers should make laws to allow the most appropriate scale of operations in pursuit of maximum efficiency. Cooperation that crosses political boundaries to reduce operating costs and ensure that there is sufficient waste to incinerate can help achieve optimal efficiency. However, on a policy level, Chao [31] 
mentioned that cross-boundary cooperation often involves political, economic, and organizational barriers. These include vertical confrontation between the central and local governments (or political parties), internal conflicts within administrations and among leaders, and insufficient rule of law.

In reality, cross-boundary cooperation in Taiwan are plagued with a lack of legal framework, opposition from opposing political parties, and local leaders pursuing their own agendas. It has become absolutely essential to establish a unit dedicated to coordinating cross-boundary cooperation. The United States government has more than 1000 interagency or interdepartmental committees to help policy-makers in various organizations cooperate [32]. Liu and Hsu [33] recommended that Taiwan could consider Germany's experience and create an organization to establish rule of law and promote cross-boundary cooperation. This research also concluded that applying cross-boundary cooperation mechanisms, the quantity of trash available for incineration in each county could be adjusted according to their own circumstances. This would allow each incinerator to treat an appropriate quantity of trash. Combined with the establishment of a sensible system of private oversight, this could potentially solve Taiwan's incinerator management and operation problems.

\section{Conclusions}

This study analyzes and assesses the TEPA's proposed options for resolving the crisis in Taitung. To minimize the financial burden, possible costs are categorized into: (1) compensation in installments for the construction company; (2) refurbishing/mothballing costs; and (3) operating expenses and/or treatment costs of transporting trash to other incinerators. After careful comparisons, Option (III) — Mothballing looks superior to Option (I)—Refurbishing for normal operation and Option (II)-Maintaining functionalities. However, the TEPA did not seem to take into consideration the future expenditures of re-activating the incinerator. This study thus argues that Option (III) seemed to bring the optimal scenario and resolved the crisis politically. Yet, in reality, this incinerator can be considered "mothballed and ultimately pensioned off" due to economic and technical obstacles of re-activating the incinerator.

In sum, this study concludes that for a BOT/BOO project to succeed, there needs to be high financial feasibility, great administrative efficiency, successful partnership between private and public sectors, and less interference from political concerns. In the case study of the construction of the Taitung incinerator, there was an erroneous estimate of the quantity of waste material. It ultimately results in political and legal disputes that lead to the policy failure. The market-based revenue model used in this BOT/BOO project included demand risk that affected both financial planning and operations. However, the BOT/BOO model has the advantage of reducing the financial burden on governments. We believe the BOT/BOO model is still a viable administrative tool, but it requires proper policy monitoring and evaluation to keep managing risks at bay. In the case study, the policy was set out right, but in the end, it failed because of incapability in managing risks.

No matter how well they are planned, large scale development programs all have associated risks. BOT/BOO projects are no exception. Governments can simultaneously promote several urgently needed construction projects, even with limited time and financial resources. Additionally, management techniques from private sectors can increase the efficiency of public construction planning and execution. Since many developing countries adopt the BOT/BOO model to build public facilities for environmental protection, we sincerely believe that our study can serve as a useful reference in the international arena. The BOT/BOO model of attracting private investors to participate in public environmental construction projects promotes a city's sustainability in the long run. Future public works projects related to environmental protection could also use BOT/BOO model, but the government should learn from the mistakes of the Taitung incinerator case and do a better job of evaluating policy to avoid another failure. To ensure success of such projects in the future, further research efforts can be directed to areas including careful financial analysis, broader collection of public opinions, proper control of political influences, and more attention to contract reasonableness. 
Acknowledgments: This research is financially supported by the Ministry of Science and Technology, Taiwan, under the Grant number of MOST105-2621-M-305-005. We thank all interviewees for their valuable input. We also thank Giin-Tarng Hwang for comments on an early draft of the manuscript.

Author Contributions: Both authors have made substantial contributions in conceptualizing the research design, reviewing and analyzing extensive literature, and developing and delivering the final research results. The final version has been approved by both authors.

Conflicts of Interest: The authors declare no conflict of interest.

\section{References and Notes}

1. Andrews, R.; van de Walle, S. New public management and citizens' perceptions of local service efficiency, responsiveness, equity and effectiveness. Public Manag. Rev. 2013, 15, 762-783. [CrossRef]

2. Hsu, L.W. Government supervision of and state responsibility for private participation in public works projects: The case of BOT projects for major transportation infrastructure. Socioecon. Law Inst. Rev. 2011, 47, 133-173. (In Chinese)

3. Savas, E.S. Privatization and Public-Private Partnerships; Chatham House Publishers: New York, NY, USA, 2000.

4. Ashuri, B.; Kashani, H.; Molenaar, K.R.; Lee, S.; Lu, J. Risk-neutral pricing approach for evaluating BOT highway projects with government minimum revenue guarantee options. J. Constr. Eng. Manag. 2012, 138, 545-557. [CrossRef]

5. Khan, A.H.; Sharif, M.B.; Rehman, Z.U. Constraints in adoption of Build Operate and Transfer (BOT) projects in developing countries-Fact findings from Pakistan. Pak. J. Sci. 2012, 64, 12-18.

6. Zhao, Z.Y.; Zuo, J.; Zillante, G. Factors influencing the success of BOT power plant projects in China: A review. Renew. Sustain. Energy Rev. 2013, 22, 446-453. [CrossRef]

7. Zhao, Z.Y.; Zuo, J.; Zillante, G.; Wang, X.W. Critical success factors for BOT electric power projects in China: Thermal power versus wind power. Renew. Energy 2010, 35, 1283-1291. [CrossRef]

8. Ministry of Finance. Act for Promotion of Private Participation in Infrastructure Projects. Amended Date: 30 December 2015. Available online: http://law.moj.gov.tw/Eng/LawClass/LawContent.aspx?PCODE= D0070062 (accessed on 20 September 2016).

9. Wang, M.S.; Zeng, Y.S. Performance studies on governance of local infrastructure by BOT modes: Viewpoints of governance structure. J. Public Adm. 2011, 38, 49-73. (In Chinese)

10. Su, N. The arbitration of BOT contract disputes on construction. Natl. Chung Cheng Univ. Law J. 2011, 35, 155-208. (In Chinese)

11. Kang, C.C.; Feng, C.M. Risk measurement and risk identification for BOT projects: A multi-attribute utility approach. Math. Comput. Model. 2009, 49, 1802-1815. [CrossRef]

12. Tang, L.Y.; Shen, Q.; Cheng, W.L. A review of studies on public-private partnership projects in the construction industry. Int. J. Proj. Manag. 2010, 19, 195-205. [CrossRef]

13. Prasanta, K.D.; Ogunlana, S.O. Selection and application of risk management tools and techniques for build-operate-transfer projects. Ind. Manag. Data Syst. 2004, 104, 334-346.

14. Taiwan Environmental Protection Administration (TEPA). Waste Disposal Act. Amended Date: 29 May 2013. Available online: http:/ /law.moj.gov.tw/Eng/LawClass/LawContent.aspx?PCODE=O0050001 (accessed on 20 September 2016).

15. Taitung County Government. Information Disclosure: Official Announcement Regarding the Arbitral Award of Taitung BOO Waste Incineration Plant's Built and Operational Work. Available online: http:/ /www.taitung.gov.tw /News_Content.aspx?n=E4FA0485B2A5071E\&s=BAFCB709A8FAA1DF (accessed on 20 September 2016).

16. Environmental Protection Administration (TEPA). Financial Analysis Programs after Taitung BOO Incineration Plant Arbitration; Environmental Protection Administration: Taipei, Taiwan, 2012. Available online: http:/ /epq.epa.gov.tw /EPQ_ResultDetail.aspx?proj_id=1036214550\&recno=\&document_id=15032 (accessed on 20 September 2016).

17. Shen, S.H. The Minister of TEPA. Interview, 19 March 2014.

18. Chen, A.; Subprasom, K. Analysis of regulation and policy of private toll roads in a build-operate-transfer scheme under demand uncertainty. Transp. Res. Part A 2007, 41, 537-558. [CrossRef] 
19. Chiou, C.T. From NIMBY to YIMBY: Problem and solutions of environmental protest in Taiwan. Taiwan J. Political Sci. 2002, 17, 33-56. (In Chinese)

20. Gerston, L.N. Public Policy Making: Process and Principles; Routledge: Armonk, NY, USA, 2004.

21. Yu, J.X.; Qu, Z.Y. PPPs: Inter-actor relationships two cases of home-based care services in China. Public Adm. Q. 2012, 36, 238-264.

22. Tam, C.M. Build-operate-transfer model for infrastructure developments in Asia: Reasons for successes and failures. Int. J. Proj. Manag. 1999, 17, 377-382. [CrossRef]

23. Feng, Z.; Zhang, S.B.; Gao, Y. Modeling the impact of government guarantees on toll charge, road quality and capacity for Build-Operate-Transfer (BOT) road projects. Transp. Res. Part A 2015, 78, 54-67. [CrossRef]

24. Chen, D.C. Former Director of the Taitung Incinerator. Interview, 18 March 2014.

25. Zheng, S.; Tiong, L.K. First public-private-partnership application in Taiwan's wastewater treatment sector: Case study of the Nanzih BOT wastewater treatment project. Int. J. Proj. Manag. 2010, 136, $913-922$. [CrossRef]

26. Kumaraswamy, M.M.; Zhang, X.Q. Governmental role in BOT-led infrastructure development. Int. J. Proj. Manag. 2001, 19, 195-205. [CrossRef]

27. Qiu, L.D.; Wang, S. BOT projects: Incentives and efficiency. J. Dev. Econ. 2011, 94, 127-138. [CrossRef]

28. Hanaoka, S.; Palapus, H.P. Reasonable concession period for build-operate-transfer road projects in the Philippines. Int. J. Proj. Manag. 2012, 30, 938-949. [CrossRef]

29. Niu, B.; Zhang, J. Price, capacity and concession period decisions of pareto-efficient BOT contracts with demand uncertainty. Transp. Res. Part E 2013, 53, 1-14. [CrossRef]

30. Tang, C.P.; Chen, C.C. New public management and NIMBY politics: The case of garbage management cooperation between Chiayi city and county. Taiwan J. Political Sci. 2005, 23, 101-132. (In Chinese)

31. Chao, Y.M. The inter-governmental relations and regional governance of Taiwan: A literature review and strategy analysis. Taiwan J. Political Sci. 2003, 18, 53-70. (In Chinese)

32. Lindblom, C.E. The Policy-Making Process; Yale University Press: New Haven, CT, USA, 1984.

33. Liu, M.T.; Hsu, Y.C. Analysis on the model and case of cross-boundary cooperation among local governments between Taiwan and Germany. Public Adm. 2011, 41, 37-72. (In Chinese)

(C) 2016 by the authors; licensee MDPI, Basel, Switzerland. This article is an open access article distributed under the terms and conditions of the Creative Commons Attribution (CC-BY) license (http://creativecommons.org/licenses/by/4.0/). 